\title{
LITERASI KETAHANAN PANGAN BERBASIS PHOTOVOICE DENGAN MODEL GI TERHADAP KEPEDULIAN DAN HASIL KARYA TULIS ILMIAH KIR
}

\author{
Luh Eka Sri Purnami, Dewa Ayu Puspawati, Cornelius Sri Murdo Yuwono \\ Program Studi Pendidikan Biologi, FKIP UNMAS Denpasar \\ Email: ekasripurnami@gmail.com
}

\begin{abstract}
ABSTRAK
Ketahanan pangan telah menjadi perhatian pada lingkup nasional dan internasional. Namun selama ini belum banyak diintegrasikan ke dalam pendidikan, sehingga berdampak pada rendahnya kepedulian peserta didik terhadap ketahanan pangan. Salah satu solusi untuk mengatasi hal tersebut adalah menerapkan literasi ketahanan pangan berbasis photovoice dengan model Group Investigation. Tujuan penelitian adalah untuk menganalisis kepedulian dan hasil karya tulis ilmiah KIR melalui literasi ketahanan pangan berbasis photovoice dengan model Group Investigation. Desain penelitian menggunakan Quasi Experimental Design dengan rancangan Nonequivalent Control Group Design. Populasi adalah seluruh siswa Kelompok Ilmiah Remaja kelas X di SMA (SLUA) Saraswati 1 Denpasar semester genap tahun pelajaran 2015/2016. Sampel adalah siswa kelas X MIA 1 (control) dan X MIA 2 (eksperimen). Teknik pengumpulan data kepedulian peserta didik menggunakan angket kepedulian dan hasil karya tulis ilmiah menggunakan rubrik penilaian hasil karya tulis ilmiah. Analisis data menggunakan uji Mann Whitney U-test. Hasil penelitian menunjukkan terdapat perbedaan kepedulian dan hasil karya tulis ilmiah antara kelas kontrol dan kelas eksperimen dengan taraf signifikansi $(\mathrm{p}=0,000<0,05)$. Kesimpulan bahwa literasi ketahanan pangan berbasis photovoice dengan model GI berpengaruh terhadap peningkatan kepedulian dan hasil karya tulis ilmiah Kelompok Ilmiah Remaja.
\end{abstract}

Kata kunci: Literasi Ketahanan Pangan, Fotovoice, Investigasi Kelompok, Kesadaran, Makalah Ilmiah

Food security has become a concern at national and international scope. Recently, food security has not been widely integrated into education, so the impact is students' low awareness on it. One solution to overcome the situation is to raise food security literacy by using photovoice through Group Investigation learning model. The purpose of this study is to analyze the awareness and score of students' scientific paper through the aforementioned methods. Quasi-Experimental Design with Nonequivalent Control Group Design was used. The population was all students of Youth Science Group in X class of SMA (SLUA) Saraswati 1 Denpasar in the second semester of academic year 2015/2016. Sample used were students of X MIA 1 as a control and X MIA 2 as an experimental class. Data collection technique for gaining awareness of students was distributing questionnaires of awareness Assessment results of scientific paper was then assessed by using rubric. Data analysis technique usedwas Mann-Whitney $U$ test. The results of quantitative research show that there wasa difference on the awareness and score of scientific paper between the control and the experimental class with the significant degree of $p=0.000<0.05$. In conclusion, the food 
security literacy based on photovoice in Group Investigation learning model increased the awareness and score of students' scientific paper.

Keywords: Literacy of Food Security, Photovoice, Group Investigation, Awareness, Scientific Papers

\section{PENDAHULUAN}

Ketahanan pangan merupakan suatu hal yang utama dalam pembangunan guna mencapai kesejahteraan masyarakat. Komitmen Indonesia untuk mewujudkan ketahanan pangan tertuang dalam Undang - Undang (UU) No. 18 tahun 2012 pada pasal 1 ayat 4 yang mendefinisikan ketahanan pangan sebagai kondisi terpenuhinya pangan bagi negara sampai dengan perseorangan, yang tercermin dari tersedianya pangan yang cukup, baik jumlah maupun mutunya, aman, beragam, bergizi, merata, dan terjangkau serta tidak bertentangan dengan agama, keyakinan, dan budaya masyarakat, untuk dapat hidup sehat, aktif, dan produktif secara berkelanjutan.Upaya pencapaian ketahanan pangan telah menjadi perhatian pada lingkup nasional dan internasional (Dewan Ketahanan Pangan, 2015). Melihat hal tersebut,upaya mencapai ketahanan pangan pada suatu negara memang bukan persoalan sederhanadan selama ini ketahanan pangan belum banyak diintegrasikan ke dalam pendidikan. Namun sebagai warga negara Indonesia kita wajib untuk meningkatkan kepedulian mengenai ketahanan pangan terutama dari lingkup terkecil, salah satunya adalah melalui lingkungan sekolah.

Pendidikan di sekolah memiliki peranan yang cukup penting dalam menjaga ketahanan pangan suatu negara, karena pendidikan tentunya akan menentukan masa depan suatu bangsa.
Selain itu, ada kecenderungan para pelajar di tanah air makin berorientasi pada pangan non lokal dan lebih suka mengkonsumsi makanan cepat saji dengan lisensi luar negeri dibanding makanan yang terbuat dari aneka biji-bijian atau umbi-umbian lokal. Hal ini jika dibiarkan, maka sasaran menuju ketahanan pangan tidak akan tercapai dan sebaliknya generasi muda makin tergantung pada pangan non lokal. Keberhasilan siswa sebagai calon pemimpin masa depan dalam memperjuangkan agar bangsa dan negara sejajar dengan negara maju lainnya, ditentukan oleh tingkat keberpihakannya terhadap sistem pangan lokal (Surata, 2015).

Hasil observasi dan wawancara di SMA (SLUA) Saraswati 1 Denpasar menunjukkan bahwa banyak karya tulis yang telah dihasilkan oleh peserta didikanggota kelompok ilmiah remaja tersebut, namun selama ini karya ilmiah mereka belum pernah mengangkat ketahanan pangan lokal sebagai tema penelitian, padahal pangan lokal merupakan suatu ciri khas yang menunjukkan kearifan lokal dan terjaganya ketahanan pangan suatu daerah. Berdasarkan pernyataan tersebut dalam kegiatan KIR diperlukan suatu inovasi dalam pembelajaran berupa model pembelajaran yang dapat melibatkan partisipasi aktif siswa dan meningkatkan kemampuan sosial siswa. Taniredja, dkk., (2014) menyatakan salah satu model pembelajaran yang dapat membimbing 
para siswa mengembangkan kemampuan afektif, kognitif dan psikomotor adalah model pembelajaran Group Investigation. Hasil penelitian Dewi, $d k k$., (2013) menyimpulkan bahwa penggunaan model pembelajaran Group Investigation dengan media photovoice efektif diterapkan dalam meningkatkan perilaku berkelompok siswakelompok ilmiah remaja.

Berdasarkan latar belakang tersebut, maka dirancang sebuah penelitian yang bertujuan untuk mengkaji lebih lanjut mengenai literasi ketahanan pangan berbasis photovoice denganmodel Group Investigation terhadap kepedulian dan hasil karya tulis ilmiahpeserta didik anggota KIRSMA (SLUA) Saraswati 1 Denpasar.

\section{METODE PENELITIAN}

Penelitiandilaksanakan dari bulan Februari sampai Mei 2016 di SMA (SLUA) Saraswati 1 Denpasar. Untukmenentukan sampel dalam penelitian ini,dari seluruh peserta didik anggota KIR kelas $\mathrm{X}$ yang berjumlah 4 kelas diundi secara acak sehingga di dapatkan peserta didik kelas $X$ MIA 2 sebagai kelas eksperimen dan peserta didik kelas X MIA1 sebagai kelas kontrol.

Jenis penelitianadalah Quasi Experimental Design dengan rancangan Nonequivalent Control Group Design (Sugiyono, 2014). Sebelum pembelajaran dimulaipeserta didik diberikan pretes berupa angket kepedulian lingkungan dengan 33 pernyataan untuk mengetahui kepedulian peserta didik sebelum dilaksanaan pembelajaran. Pembelajaran dilaksanakan di dalam kelas dan di luar kelas, di dalam kelas kegiatan yang dilakukan peserta didik adalah memperhatikan materi pengantar mengenai ketahanan pangan yang disajikan dengan media power point dan video yang berkaitan dengan ketahanan pangan serta diberikan penjelasan singkat mengenai photovoice.Sedangkan kegiatan di lingkungan sekitar tempat tinggal peserta didik adalah mencari gambar/foto secara berkelompok sesuai topik yang diberikan. Gambar/foto tersebut akan dirancang menjadi sebuah media pembelajaran photovoice yang disajikan dalam bentuk power pointsebagai hasil dari investigasi kelompok. Hasil investigasi kelompok didiskusikan di dalam kelompok sebagai bahan presentasi di dalam kelas dan ide untuk pembuatan karya tulis ilmiah. Hasil akhir karya tulis ilmiah peserta didik dinilai menggunakan rubrik penilaian karya tulis ilmiah.

Instrumen berupa angket divalidasi secara isi (content validity) terlebih dahulu, selanjutnya pengujian validitas angket menggunakan korelasi Product Moment Person(Arikunto, 2012). Pada penelitian ini perhitungan korelasi product moment yang dilakukan menggunakan program komputer SPPS hasil yang didapat dengan signifikansi item yaitu $(\mathrm{p}=0,000<0,05)$ sehinggaangket kepedulian dengan 33 pernyataan dapat dikatakan valid dan siap digunakan. Uji reliabilitas angket dilakukan dengan uji Alpha Cronbach (Sugiono, 2014). Nilai alpha cronbach yang didapat berdasarkan hasil perhitungan adalah 0,700 , berarti angket kepedulian lingkungan adalah reliabel. Sedangkan penilaian hasil karya tulis ilmiah peserta didik tidak divalidasi karena rubrik hasil karya tulis ilmiah ini telah valid dan sering digunakan dalam penilaian karya tulis ilmiah di tingkat 
nasional yaitu dalam penilaian karya tulis ilmiah Program Kreativitas Mahasiswa (PKM) (Ristekdikti, 2015).

Data dianalisis dengan menggunakan analisis deskriptif dan inferensial. Analisis deskriptif dilakukan dengan analisis Gain Score (Hake, 1999) untuk menganalisis peningkatan kepedulian peserta didik. Analisis inferensial menggunakan uji statistikMann Whitney U Test. Analisis ini dilakukan untuk mengetahui adanya perbedaan kepedulian dan hasil karya tulis ilmiah peserta didik yang dibelajarkan literasi ketahanan pangan berbasis photovoice dengan model Group Investigation dengan peserta didik yang tidak dibelajarkan dengan model Group Investigation.

\section{HASILDAN PEMBAHASAN Analisis Kepedulian Peserta Didik}

Kepedulian peserta didik dinilai menggunakan angket kepedulian yang terdiri dari 33 pernyataan dengan 5 aspek kepedulian meliputi memelihara (MLH), memperhatikan (MPH), melestarikan (MST), adanya minat atau rasa tertarik (AMT) dan adanya kesadaran (AKD). Angket diberikan pada kelas kontrol dan kelas eksperimen sebelum (pretest) dan sesudah (posttest) mengikuti proses pembelajaran. Hasil mengenai distribusi frekuensi kategori kepedulian peserta didik pada kelas kontrol dan kelas eksperimen berdasarkan nilai gain scoreterdapat pada Tabel 1.

Tabel 1.Distribusi Frekuensi Kategori Kepedulian Berdasarkan Nilai Gain Score

\begin{tabular}{|c|c|c|c|c|c|c|}
\hline \multicolumn{7}{|c|}{ Kepedulian Siswa } \\
\hline \multirow[t]{2}{*}{ No. } & \multirow{2}{*}{ Interval } & \multirow{2}{*}{ Klasifikasi } & \multicolumn{2}{|c|}{$\begin{array}{l}\text { Kelas Kontrol } \\
\qquad(\mathrm{N}=\mathbf{4 5})\end{array}$} & \multicolumn{2}{|c|}{$\begin{array}{c}\text { Kelas } \\
\text { Eksperimen } \\
(\mathrm{N}=46)\end{array}$} \\
\hline & & & $\begin{array}{l}\text { Gain } \\
\text { Score }\end{array}$ & $\%$ & $\begin{array}{l}\text { Gain } \\
\text { Score }\end{array}$ & $\%$ \\
\hline 1 & $\geq 0,7$ & Sangat Baik & 0 & 0.00 & 28 & 60,87 \\
\hline 2 & $\geq 0,3-<0,7$ & Baik & 26 & 57,78 & 18 & 39,13 \\
\hline 3 & $<0,3$ & Cukup & 19 & 42,22 & 0 & 0.00 \\
\hline
\end{tabular}

Ditinjau dari nilai gain score aspek kepedulian peserta didik, terdapat perbedaan antara kelas eksperimen dengan kelas kontrol. Perbandingan nilai gain score aspek-aspek kepedulian peserta didik pada kelas eksperimen dan kelas kontrol terdapat pada Gambar 1. 


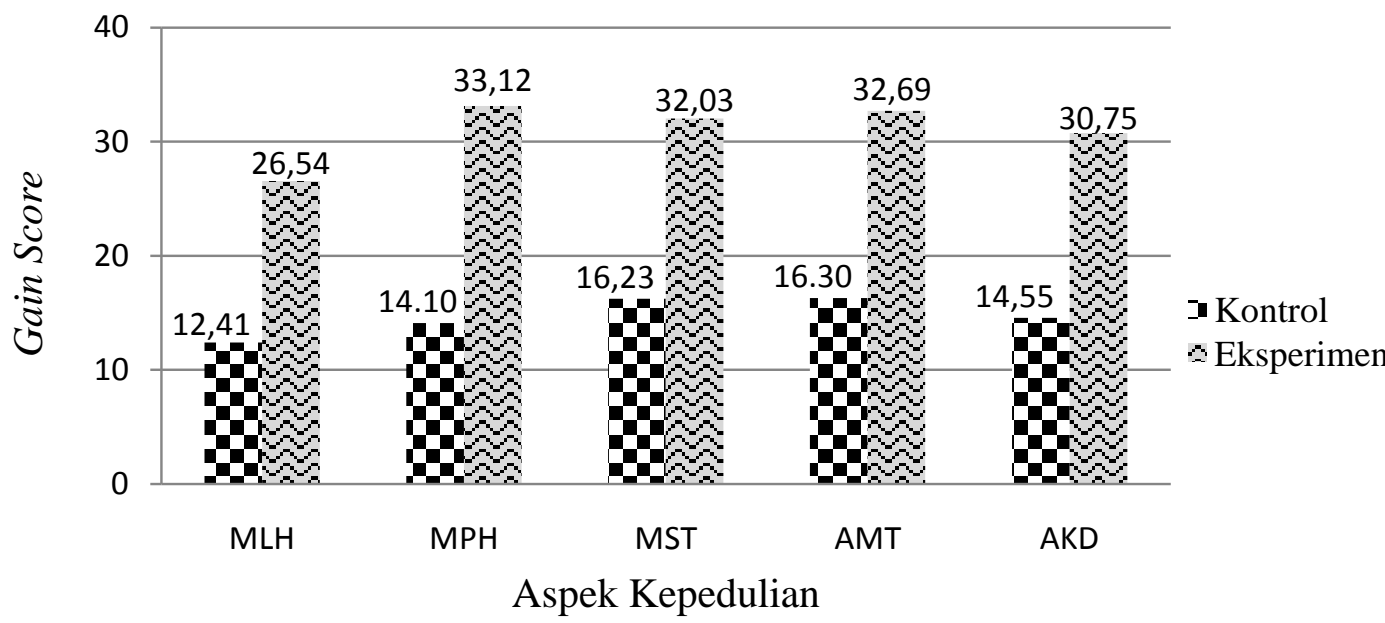

Gambar 1. Perbedaan Nilai Gain Score Kepedulian Berdasarkan Aspek yang Diukur Keterangan: Memelihara (MLH), Memperhatikan (MPH), Melestarikan (MST), Adanya Minat atau Rasa Tertarik (AMT) dan Adanya Kesadaran (AKD)

Jika ditinjau berdasarkan aspek kepedulian yang diukur kelas eksperimen memperoleh skor lebih tinggi dibandingkan kelas kontrol. Hal ini diperkuat dengan hasil uji Mann Whitney $U$ Test terhadap kepedulian peserta didik menunjukkan perbedaan nyata antara kelas kontrol dengan kelas eksperimen dengan signifikansi $\quad(\mathrm{p}=0.000<0.5)$. Sedangkan ditinjau dari masing-masing aspek kepedulian peserta didik yaitu MLH, MPH, MST, AMT, dan AKD menunjukkan perbedaan nyata antara kelas kontrol dan kelas eksperimen dengan signifikasi $(\mathrm{p}=0,000<0,05)$. Sehingga dari hasil uji Mann Whitney U Test tersebut menunjukkan bahwa jika peserta didik dibelajarkan literasi ketahanan pangan berbasis photovoice dengan model pembelajaran Group Investigation maka kepedulian peserta didik lebih baik dibandingkan dengan peserta didik yang tidak dibelajarkan dengan model pembelajaran Group Investigation.

\section{Analisis Perbedaan Hasil Karya Tulis Ilmiah}

Peserta didik secara berkelompok membuat karya tulis ilmiah berdasarkan hasil kegiatan investigasi kelompok yang dilakukan di lingkungan sekitar tempat tinggal peserta didik. Pada kelas kontrol menghasilkan 9 karya tulis ilmiah dan pada kelas eksperimen menghasilkan 9 karya tulis ilmiah, sehingga ada 18 karya tulis ilmiah yang dihasilkan dengan tema ketahanan pangan. Penilaiankarya tulis ilmiah peserta didik berdasarkan 8 aspek yang diamati yaitu : judul (JU), abstrak $(\mathrm{AB})$, pendahuluan (PE), tujuan (TU), metode (ME), hasil dan pembahasan (HP), kesimpulan (KE), dan daftar pustaka (DP). Perhitungan nilai karya tulis ilmiah merupakan hasil kali antara bobot dengan skor. Bobot pada setiap aspek yaitu JU (5\%), AB (10\%), PE (10\%), TU (5\%), ME (25\%), HP (30\%), KE (10\%), dan DP (5\%) dengan skala penskoran 1-7. Penilaian hasil karya tulis ilmiah dilakukan pada kelas eksperimen dan kelas kontrol oleh guru Pembina KIR, peneliti dan 
seorang observer. Ditinjau dari masingmasing kriteria penilaian yang terdapat pada rubrik penilaian hasil karya tulis ilmiah peserta didik anggota KIR terdapat perbedaan antara kelas kontrol dan kelas eksperimen seperti pada Gambar 2.

Gambar 2.Perbandingan Jumlah Nilai Karya Tulis Ilmiah Berdasarkan Kriteria Penilaian yang Diukur.

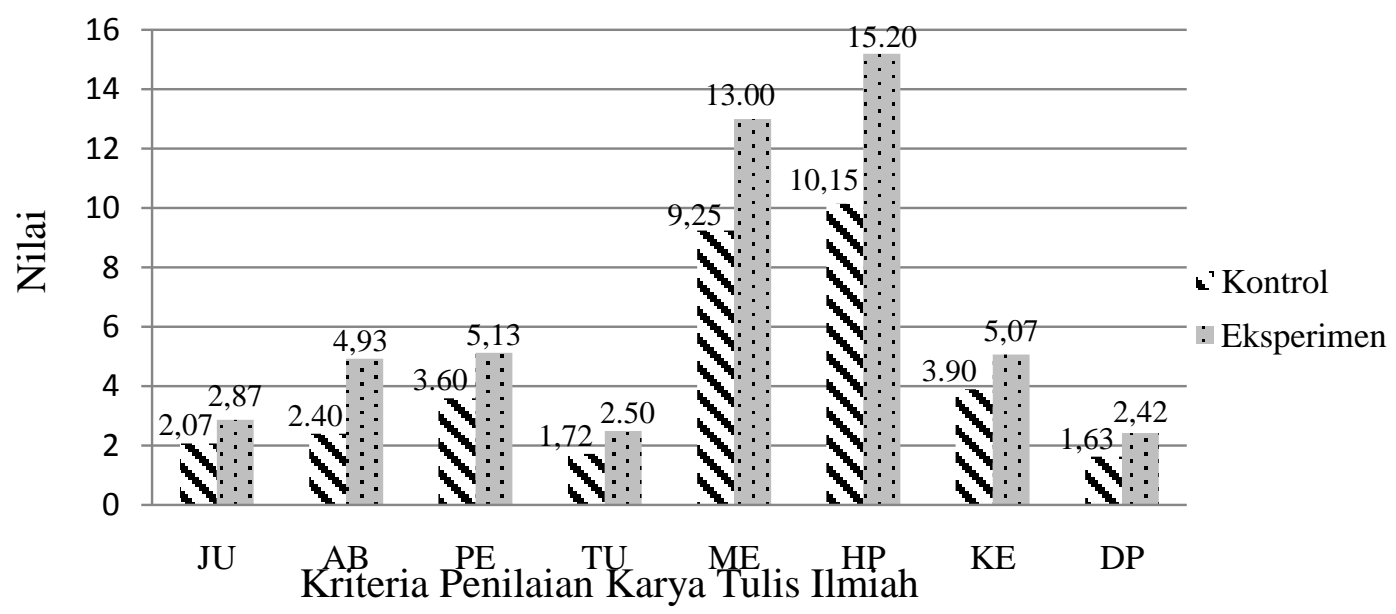

Keterangan : Judul (JU), Abstrak (AB), Pendahuluan (PE), Tujuan (TU), Metode (ME), Hasil dan Pembahasan (HP), Kesimpulan (KE), dan Daftar Pustaka (DP)

Berdasarkan hasil perbandingan pada Gambar 2. kriteria penilaian yang memperoleh nilai tertinggi pada kelas eksperimen yaitu HP $(15,20)$ dan kriteria penilaian yang memperoleh nilai terendah yaitu DP $(2,42)$. Sedangkan pada kelas kontrol kriteria penilaian yang memperoleh nilai tertinggi yaitu HP $(10,15)$ dan kriteria penilaian yang memperoleh nilai terendah yaitu DP (1,63). Ditinjau dari segi kelompok terlihat kelompok eksperimen memperoleh nilai lebih tinggi dibandingkan kelompok kontrol, perbandingan penilaian hasil karya tulis ilmiah pada kelas eksperimen dan kelas kontrol berdasarkan jumlah nilai masingmasing kelompok terdapat pada Gambar 3.

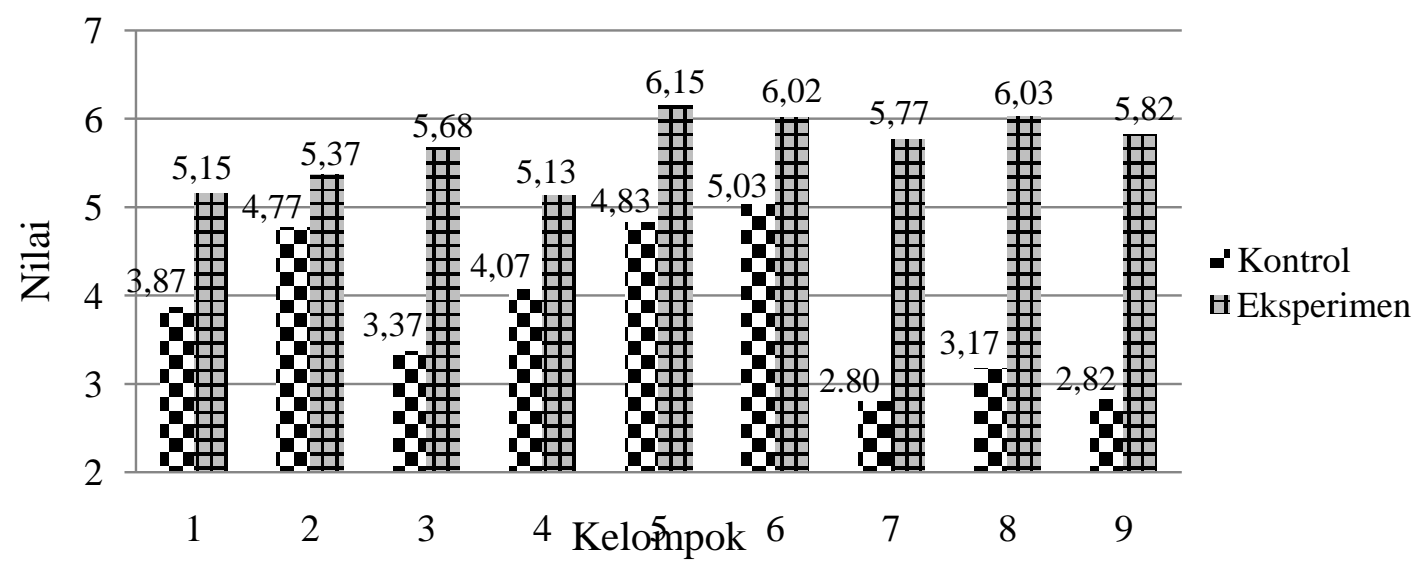

Gambar 3. Perbandingan Jumlah Nilai Karya Tulis Ilmiah Kelompok Kelas Kontrol dan Kelas Eksperimen. 
Berdasarkan hasil uji Mann Whitney $U$ Test terhadap hasil karya tulis ilmiah peserta didik menunjukkan perbedaan nyata antara kelas kontrol dengan kelas eksperimen, dengan signifikansi $(\mathrm{p}=0.000<0.5)$. Ditinjau dari masingmasing kriteria penilaian karya tulis ilmiah antara kelas kontrol dan kelas eksperimen, hasil uji Mann Whitney $U$ Test menunjukkan terdapat perbedaan nyata pada setiap kriteria penilaian yaitu pada JU $(\mathrm{p}=0,001<0,05), \mathrm{AB}(\mathrm{p}=0,000<0,05), \mathrm{PE}$ $(p=0,001<0,05), T U(p=0,000<0,005), \mathrm{ME}$ $(\mathrm{p}=0,002<0,05), \quad \mathrm{HP}(\mathrm{p}=0,001<0,05), \mathrm{KE}$ $(\mathrm{p}=0,003<0,05)$, dan DP $(\mathrm{p}=0,001<0,05)$. Berdasarkan hasil uji Mann Whitney U Test tersebut menunjukkan bahwa jika peserta didik dibelajarkan literasi ketahanan pangan berbasis photovoice dengan model Group Investigation maka hasil karya tulis ilmiah peserta didik berbeda dengan peserta didik yang tidak dibelajarkan dengan model pembelajaran Group Investigation.

\section{PEMBAHASAN}

\section{Pembahasan Kepedulian Peserta Didik}

Kepedulian pada kelas eksperimen memperoleh rata-rata skor lebih tinggi dibandingkan kelas kontrol. Hal ini dikarenakan model Group Investigation lebih melibatkan peserta didik dalam proses pembelajaran dan melatih peserta didik agar memiliki kemampuan yang baik dalam berkomunikasi maupun keterampilan proses kelompok, sehingga kepedulian lebih meningkat dibandingkan kelas kontrol. Hasil penelitian ini sesuai dengan hasil penelitian Kurniawati (2013) bahwa model Pembelajaran Group Investigation mampu meningkatkan kepedulian lingkungan siswa. Sedangkan pada kelas kontrol tidak dibelajarkan dengan model pembelajaran Group Investigation,lebih menekankan pada penyelesaian materi atau tugas yang diberikan oleh guru sehingga peserta didik kurang termotivasi untuk peduli.

Kategori kepedulian kelas kontrol berada pada kategori baik dan cukup, sedangkan pada kelas eksperimen pada kategori sangat baik dan baik. Nilai gain score kelas eksperimen lebih baik dari kelas control, karenamodel pembelajaran Group Investigation memberikan kesempatan kepada anggota KIR untuk berinteraksi pada lingkungan sekitar melalui kegiatan investigasi kelompok, seperti mengamati langsungdisekitar tempat tinggal peserta didik mengenai potensi pangan lokal yang dapat dikembangkan, mendiskusikan dan menganalisis fenomena ketahanan pangan yang terjadi, dan membuat sebuah karya tulis ilmiah. Kegiatan tersebut dapat meningkatkan rasa peduli peserta didik untuk lebih memperhatikan dan menjaga ketahanan pangan. Sesuai pernyataan Kurniawati (2013) bahwa kepedulian tidak dapat tumbuh begitu saja secara alamiah pada diri seseorang, namun harus diupayakan pembentukannya secara terus menerus melalui sebuah kegiatan nyata. Sejalan dengan penelitian Santoso, $d k k$., (2013) bahwa pembelajaran melalui eksperimen lapangan membuat peserta didik merasa lebih mudah memahami materi, dapat menemukan permasalahan mengenai lingkungan serta mencari solusinya, sehingga efektif dalam meningkatkan kepedulian siswa. Demikian halnya dengan hasil penelitian Handoyo (2015), yang mendapatkan bahwa kegiatan pembelajaran yang dirancang dengan topik ketahanan pangan dapat mengembangkan 
karakter peduli sosial mahasiswa dalam masalah ketahanan pangan.

Perbedaan skor peraspek kepedulian antara kelas kontrol dan eksperimen juga tampak jelas, dimana aspek memperhatikan (MPH) pada kelas eksperimen memperoleh skor tertinggi, karena pada tahap investigasi kelompok peserta didik anggota KIR harus mencari data sebanyak-banyaknya sesuai topik dengan menggunakan indra yang dimiliki. Aspek memperhatikan menuntut peserta didik menggunakan kelima indrauntuk mengindentifikasi permasalahan yang ada di lingkungan sekitar yang diamati, misalnya mengenai kesehatan makanan dan potensi pangan lokal yang dapat dijadikan topik penelitian sehingga aspek ini memperoleh skor tertinggi.

Hal tersebut sesuai dengan penelitian Sutriasih \& Puspawati (2015) yang menemukan bahwa dengan menerapkan proses pembelajaran diluar kelas peserta didik mempelajari materi secara langsung, sehingga pengetahuan dapat dikontruksi dari pengalaman peserta didikmelalui observasi dan wawancara lapangan, kemudian mengungkapkan konsep yang sesuai dengan pengalaman yang digunakan untuk memecahkan masalah serta menyimpulkan hasil diskusi kelompok sehingga kepedulian peserta didik terhadap ketahanan pangan juga mengalami peningkatan. Peserta didik dapat mengamati sendiri bagaimanaketahanan pangan disekitar mereka, dengan mengamati sendiri maka kesadaran untuk peduli pangan lokal lebih mudah untuk ditingkatkan, sehingga dapat menimbulkan minat untuk memelihara dan melestarikan ketahanan pangan.Penerapan photovoice mampu meningkatkan minat dan rasa tertarik peserta didik dalam menjaga ketahanan pangan. Karena photovoice memberikan kesempatan pada peserta didik untuk lebih aktif dan kreatif dalam mengumpulkan informasi dan data dengan menggunakan sasaran lensa.

Penerapan photovoicepada kelas kontrol memberikan pengaruh pada aspek minat dan rasa tertarik (AMT) menjaga ketahanan pangan sehingga aspek tersebut memperoleh skor tertinggi, karena kegiatan pengambilan foto merupakan kegiatan interaktif yang bermakna dan menyenangkan. Hal ini sesuai dengan hasil penelitian Surata (2013) bahwa pembelajaran dengan menggunakan media foto dapat berlangsung dalam suasana menyenangkan. Sehingga pembelajaran yang berlangsung dalam suasana menyenangkan dapat memicu semangat peserta didik untuk berpartisipasi aktif dalam kegiatan yang dilakukan.

Aspek memelihara (MLH) pada kelas kontrol maupun kelas eksperimen memperoleh skor terenda karena pada proses pembelajaran dalam kegiatan KIR lebih menekankan pada kegiatan observasi, wawancara dan eksperimen untuk memperoleh informasi dan data untuk merancang karya tulis ilmiah, sehingga kepedulian yang berkenaan dengan memelihara atau merawat tanaman pangan belum optimal, selain itu kurang adanya tanaman pangan lokal di lingkungan sekolah dan juga di lingkungan sekitar peserta didik, menyebabkan kepedulian dalam memelihara tanaman pangan lokal mengalami peningkatan terendah dibandingkan aspek yang lain.

\section{Hasil Karya Tulis Ilmiah}


Hasil karya tulis ilmiah pada kelas eksperimen memperoleh nilai lebih tinggi dibandingkan kelas kontrol. Perbedaan ini disebabkan pada kelas eksperimen peserta didik berperan aktif melakukan kegiatan pembelajaran, mulai dari tahap perencanaan, investigasi hingga menyusun sebuah karya tulis ilmiah. Selain itu model pembelajaran Group Investigationdapat melatih peserta didik lebih berani dalam menuangkan ide-ide dalam kelompok, meningkatkan kualitas interaksi antar anggota kelompok, dan saling terbuka dalam memberikan masukan dan saran. Sedangkan pada kelas kontrol karena pembelajaran masih berpusat pada guru peran peserta didik dalam pembuatan karya tulis ilmiah terbatas, karena harus menunggu instruksi guru terlebih dahulu.Selain belum ada pembagian tugas dan tanggung jawab yang jelas pada masing-masing anggota kelompok, menyebabkan adanya dominasi dari peserta didik yang berkemampuan akademik atas, akibatnya kualitas interaksi antar anggota kelompok rendah dan rendahnya partisipasi aktif anggota kelompok dalam mengerjakan karya tulis ilmiah.

Berdasarkan hasil penilaian karya tulis ilmiah terdapat perbedaan nilai yang dihitung berdasarkan masing-masing kriteria penilaian pada kelas kontrol dan eksperimen. Hasil dan pembahasan (HP) pada penilaian karya tulis ilmiah merupakan kriteria yang memiliki bobot tertinggi dibandingkan dengan kriteria yang lainnya, sehingga peserta didik pada kelas eksperimen maupun kelas kontrol lebih menekankan kriteria tersebut untuk dibuat sebaik-baiknya, akibatnya diperoleh nilai tertinggi pada kelas eksperimen maupun kelas kontrol. Berbeda halnya dengan daftar pustaka (DP), kriteria penilaian dengan bobot lebih rendah, peserta didik pada kelas eksperimen maupun kelas kontrol kurang terfokus dalam pengutipan sumber pustaka dan pada beberapa kelompok belum menuliskannya berdasarkan aturan yang telah ditentukan, sehingga penilaian untuk daftar pustaka memperoleh skor yang lebih rendah dibandingkan dengan kriteria lainnya.Namun pada kelas eksperimen memiliki nilai HP dan DP yang lebih tinggi dibandingkan dengan nilai HP dan DP pada kelas kontrol, hal ini dikarenakan pada kelas eksperimenpada tahap investigasi kelompok mampu melatih peserta didik untuk mengembangkan kemampuan siswa dalam berargumentasi dan mengorganisasikan fakta/data secara jelas dan sistematik sehingga memberikan kontribusi yang positif terhadap penulisan karya tulis ilmiah. Hasil penelitian ini sejalandengan penelitian Nurhabibah (2013) bahwa terdapat hubungan yang signifikan antara kemampuan berargumentasi siswa dengan penulisan karya tulis ilmiah.

Ditinjau dari segi kelompok, kelompok kelas eksperimen memperoleh nilai lebih tinggi, dibandingkan dengan kelompok kelas kontrol. Dalam mengerjakan karya tulis ilmiahpeserta didik pada kelas eksperimen lebih antusias dalam mengerjakan tugas mereka. Kesadaran anggota sangat tinggi dalam berpartisipasi melakukan diskusi, sehingga tugas karya tulis ilmiah yang mereka kerjakan memperoleh nilai yang maksimal. Penelitian ini sesuai dengan penelitian Yumisnaini (2013) bahwa kemampuan menulis artikel pada peserta didik yang menggunakan model pembelajaran Group 
Investigation memiliki nilai rata-rata yang lebih baik danefektif diterapkan dalam meningkatkan kemampuan menulis artikel siswa. Demikian halnya dengan penelitian Alfianika, dkk., (2014) yang menemukan pembelajaran kooperatif tipe Group Investigation sangat efektif untuk membangkitkan aktivitas dan hasil belajar siswa pada materi menulis karangan ilmiah.

Penggunaan media yang inovatif berupa photovoice juga berperan dalam meningkatkan hasil karya tulis ilmiah peserta didik dikarenakan photovoice mampu meningkatkan rasa ingin tahu dan memotivasi peserta didik, sehingga peserta didik dapat mengkolaborasikan ide-ide kreatif melalui diskusi kelompok terkait dengan materi yang dibahas. Sesuai dengan hasil penelitian Mone (2014) bahwa penerapan photovoice berbasis lanskap budaya subak berpengaruh terhadap hasil karya tulis ilmiah siswa, karenaphotovoice dapat membantu siswa untuk lebih aktif dan kreatif dalam mengumpulkan informasi, sehingga informasi atau data yang didapatkan terarah dan sesuai dengan topik yang diberikan. Dan sejalan dengan hasil penelitian Partini \& Puspawati (2014) bahwa penerapan photovoice berbasis lanskap budaya subak berpengaruh pada perilaku berkelompok dan sikap sains anggota KIR. Hal ini menunjukkan bahwa photovoice sangat sesuai jika diterapkan pada kegiatan KIR karena peserta didik dapat mengembangkan ide - ide kreatif yang mereka miliki dan juga dapat belajar untuk saling bekerjasama di dalam kelompok.

\section{PENUTUP}

\section{Simpulan}

Simpulan dari hasil penelitian yang telah dilakukan yaitu kepedulian peserta didik yang dibelajarkan literasi ketahanan pangan berbasis photovoice dengan model pembelajaran Group Investigation (Gs: $60,87 \%$ )lebih baik dibandingkan peserta didik yang tidak dibelajarkan dengan model pembelajaran Group Investigation (Gs: 42,22\%) dan hasil karya tulis ilmiah peserta didik yang dibelajarkan literasi ketahanan pangan berbasis photovoice dengan model Group Investigation berbeda $(\mathrm{p}=0,000<0,05)$ dengan peserta didik yang tidak dibelajarkan dengan model pembelajaran Group Investigation

\section{Saran}

Berdasarkan temuan dalam penelitian maka saran yang dapat disampaikan antara lain sebagai berikut: (1) Bagi Peserta didik khususnya anggota KIR, diharapkan untuk tetap melatih diri menerapkan photovoice dengan mengangkat kearifan lokal sehingga pengalaman belajar bertambah, kreativitas dan kemampuan menulis karya tulis ilmiah meningkatdan mencintai pangan lokal. (2) Bagi guru Pembina KIR, dapat menerapkan pembelajaran berbasis photovoice denganmodel pembelajaran Group Investigation dalam memaksimalkan tujuan pembelajaran serta meningkatkan minat peserta didik dalam melakukan penelitian. (3) Bagi sekolah, dapat menerapkan literasi ketahanan pangan berbasis photovoice denganmodel pembelajaran Group Investigation dalam mata pelajaran dikelas, tidak hanya untuk peserta didik kelompok ilmiah remaja saja sehingga dapat meningkatkan mutu pendidikan dan generasi muda yang lebih peduli terhadap 
ketahanan pangan. (4) Bagi peneliti selanjutnya, yang berminat menggunakan karya tulis ilmiah sebagai salah satu variabel dalam melakukan penelitian, agar menambahkan satu kriteria penilaian yaitu presentasi hasil karya tulis ilmiah selain penilaian pada naskah karya tulis ilmiah, sehingga melatih kemampuan peserta didik untuk berkomunikasi, menjawab pertanyaan dan mengemukakan pendapat.

\section{UCAPAN TERIMAKASIH}

Dalam penulisan artikel ini banyak mendapat bantuan dari berbagai pihak, oleh karena itu penulis mengucapkan terimakasih kepada:

1. Bapak Prof. Dr. Sang Putu Kaler Surata, M.S, selaku dosen pengampu mata kuliah Tata Tulis Ilmiah yang telah banyak memberikan masukan terhadap penulisan artikel ilmiah ini.

2. Bapak I Nengah Rudi Artawan, S.Pd selaku guru pamong yang telah memberikan masukan, pengarahan, serta bimbingan mengenai proses pembelajaran pada siswa KIR.

\section{DAFTAR PUSTAKA}

Arikunto. (2012). Dasar - Dasar Evaluasi Pendidikan. Jakarta: Bumi Aksara

Alfianika, N., Atmazaki \& Abdurahman. (2014). Pengembangan model modul pembelajaran bahasa Indonesia berbasis investigasi kelompok (group investigation) pada materi menulis karangan ilmiah siswa kelas XI SMAN 8 Padang. Jurnal Bahasa, Sastra dan Pembelajaran. 2(2), 47-58.

Dewan Ketahanan Pangan. (2015). Peta Ketahanan dan Kerentanan Pangan Indonesia 2015. Jakarta: Dewan Ketahanan Pangan, Kementerian
Pertanian dan World Food Programme (WFP).

Dewi, S. A. M. I.U., Puspawati, D. A., \& Ismail, D. (2013). Pengaruh model pembelajaran kooperatif tipe group investigation (GI) dengan media photovoice berbasis lanskap budaya subak terhadap perilaku berkelompok siswa SMP Amarawati Tampaksiring. Jurnal Santiaji Pendidikan,3(2), 114-122

Hake, R. R. (1999). Analyzing Change / Gain Scores.[PDF Dokumen]. Diunduh dari http://www.physics.indiana.edu/ sd i/AnalyzingChange-Gain.pdf pada tanggal 10 Juni 2016

Handoyo, L. D. (2015). Penerapan service learning untuk meningkatkan kepedulian sosial mahasiswa terhadap masalah ketahanan pangan. Jurnal Penelitian, 18(2), 132-142

Kurniawati, A. (2013). Pengaruh model pembelajaran kooperatif tipe GI (group investigation) dengan memanfaatkan geopark Danau Batur sebagai media pembelajaran Ekopedagogi terhadap kepedulian lingkungan siswa. (Skripsi tidak dipublikasikan).Universitas

Mahasaraswati Denpasar, Denpasar.

Mone, L. L. (2014). Pengaruh penerapan photovoice berbasis lanskap budaya subak terhadap keterampilan proses sains dan karya tulis ilmiah remaja SMA (SLUA) Saraswati 1 Denpasar. (Skripsi tidak dipublikasikan).Universitas

Mahasaraswati Denpasar, Denpasar.

Nurhabibah, Prabawati. (2013). Korelasi 69

antara kemampuan siswa


berargumentasi dengan menulis karya ilmiah di SMA Angkasa kelas XI tahun ajaran 2012/2013. (Skripsi). Fakultas Pendidikan Bahasa dan Seni, Universitas Pendidikan Indonesia, Bandung. Diunduh dari repository.upi.edu/1408/1/S_IND_0 906911_Title.pdf pada tanggal 2 Februari 2016

Partini, N. L. K., \& Puspawati, D. A. (2014). Pengaruh photovoice berbasis lanskap budaya subak terhadap perilaku berkelompok dan sikap sains anggota KIR SMA Kristen Harapan Denpasar. Majalah Mahawidya Saraswati.8(2), 32-35

Ristekdikti. (2015). Pedoman Program Kreativitas Mahasiswa 2015. Jakarta: Direktorat Riset dan Pengabdian Masyarakat, Direktorat Jendral Penguatan Riset dan Pengembangan Kementrian Riset, Teknologi dan Pendidikan Tinggi. Diunduh dari http://simlitabmas.dikti.go.id /fileUpload/ pengumuman/Pedoman\%20PKM\% 20Tahun\%202015.pdf pada tanggal 2 Januari 2016

Santoso, A.M., Sajidan, \& Sudarisman, S. (2013). Penerapan model science technology society melalui eksperimen lapangan dan eksperimen laboratorium ditinjau dari sikap peduli lingkungan dan kreativitas verbal siswa. Jurnal Inkuiri. 2(3). 204-215. Diunduh dari http://jurnal.fkip.uns.ac.id/indeks.ph $\mathrm{p} / \mathrm{sains}$ pada tanggal 24 Januari 2016

Sugiyono. (2014). Metode Penelitian Pendidikan Pendekatan Kuantitatif,
Kualitatif, dan $R \& D$. Bandung: Alfabeta

Surata, S. P. K. (2013). Lanskap Budaya Subak. Denpasar: Unmas Press.

Surata, S. P. K. (2015). Ekopedagogi. Denpasar: Unmas Press.

Sutriasih, N. K., \& Puspawati, D. A. (2015). Penerapan siklus belajar (learning cycle) 5E dengan photovoice berbasis etnosains terhadap keterampilan proses sains siswa kelas X SMA Negeri 1 Penebel. Jurnal Santiaji Pendidikan. 5(1), 53-63

Taniredja, T., Faridli, E.M., \& Harmianto, S. (2014). Model-Model Pembelajaran Inovatif dan Efektif. Bandung: Alfabeta.

Undang- Undang Republik Indonesia (UURI) Nomor 18 Tahun 2012 Tentang Pangan, diunduh dari https://www.google.co.id/?gws_rd= $\mathrm{cr}, \mathrm{ssl} \& \mathrm{ei}=$

HukkVs7aJsvbuQTt0qTYDA\#q=uu +ketahanan+pangan+pdf, pada tanggal 2 Oktober 2015.

Yumisnaini. (2013). Efektifitas metode investigasi kelompok (group investigation) terhadap keterampilan menulis artikel oleh siswa kelas XI SMA Negeri 1 Pancurbatu tahun pembelajaran 2012/1013. [PDF Dokumen]. Diunduh dari http://jurnal.unimed.ac.id/2012/inde x.php /basastra/article/view/771.pdf pada tanggal 28 Januari 2016 